\title{
Addition of Capsicum oleoresin, Carvacrol, Cinnamaldehyde and their mixtures to the broiler diet II: Effects on meat quality
}

Hasan Hüseyin İpçak ${ }^{*}$ and Ahmet Alçiçek

\begin{abstract}
Background: In recent years, with the prohibition of antibiotics used as growth stimulants in the nutrition of farm animals, researchers have searched for alternative natural and reliable products in order to be able to sustain the developments experienced during the use of antibiotics and to overcome the possible inconveniences. In this context, studies on evaluation of essential oils in poultry nutrition have been reported to improve the utilization of feed, stimulate the release of digestive enzymes, increase absorption in the stomach and intestines, antimicrobial and anti-parasitic effects and thus, can be an alternative to antibiotics and improve meat quality as well. Indeed, this study has been carried out to explore the effects of the addition of $150 \mathrm{mg} / \mathrm{kg}$ capsicum oleoresin (CAP), carvacrol (CAR), cinnamaldehyde (CIN) or their mixture (CAP+CAR+CIN) into the broilers' ration over sensory, physical and chemical properties in breast meat and leg meat.
\end{abstract}

Methods: Experiments were conducted over 400 male and female broiler chicks (Ross-308) in 5 groups (1 control group and 4 treatment groups), each composed of 80 chicks. The control group was fed without feed additives while the second, third, fourth and the fifth groups were fed with $150 \mathrm{mg}$ CAP/ $/ \mathrm{kg}$ feed, $150 \mathrm{mg}$ CAR/kg feed, $150 \mathrm{mg}$ CIN/kg feed, and $150 \mathrm{mg} C A P+C A R+C I N / k g$ feed, respectively.

Results: Addition of CAP, CAR, CIN or CAP+CAR+CIN had effects on the sensory (of taste, tenderness, juiciness and overall acceptability); physical properties (of $L^{*}$ value and toughness), the chemical properties (of DM, CF, CP, linoleic, EPA, behenic, MUFA, PUFA and $\Sigma n-6$ of the leg meat), the physical characteristics (of toughness and firmness), and the chemical properties (of CF, CP, linoleic, ecosenic, EPA, lignoseric, MUFA and $\sum n-3$ ) of the breast meat in comparison to control group. Furthermore, while the treatments had positive impacts on thawing loss, cooking loss and water holding capacity in both breast and leg meat; no effect was observed on pH value and lipid oxidation on day 1 , day 4 and day 8.

Conclusion: The results strongly suggested that the addition of CAP, CAR, CIN or CAP+CAR+CIN to the rations of the broiler chicks changed the sensory, physical and chemical properties of breast and leg meat. It was also observed that these compounds were more effective when they were added to the ratio as a mixture rather than adding them individually.

Keywords: Broiler, Capsicum oleoresin, Carvacrol, Cinnamaldehyde, Meat quality

\footnotetext{
* Correspondence: huseyinipcak@gmail.com

Department of Animal Science, Faculty of Agricultural, Ege University,

Bornova, 35100 Izmir, Turkey
} 


\section{Background}

In recent years, foremost issues that have been interesting to all the world countries are food safety, food security and nutrition [1]. The essential requirement, probably the most important one, of individuals is nutrition to live healthy and strong in terms of physically, mentally and emotionally, to improve themselves economically and socially, for prospering and to continue themselves existence as happy, peaceful and secure [2]. It is asserted that an adult person should take $1 \mathrm{~g}$ of protein per $\mathrm{kg}$ of body weight per day in order to keep healthy and balanced diet and $42-50 \%$ of this amount should consist of animal originated proteins [3]. Chicken meat is one of the most important resources of animal protein that should be consumed for physical and mental development, healthy and balanced diet. It is an important and strategic nutrient resource since it has low cholesterol and fat ratio compared to red meat and it has healthful properties like easy digestion and being a good source of protein in terms of nutritional value as well as having low cost compared to other protein sources [4]. However, too many animals in poultryhouse during broiler breeding causes animals to be more vulnerable and less resistant and thus more susceptible to sudden state changes. Antibiotics, added into rations as feed additive in order to reduce the risk of diseases and achieve rapid live weight gain, played a crucial role until the last few years [5]. However, long-term use of these antibiotics results in the development of resistant strains against antibiotics, thus use of many antibiotics has been prohibited in the many parts of world, especially in the European Union countries since 2006 [6]. Therefore, researchers are in search of a natural and safe growth stimulant that can be an alternative product to maintain developments provided by the use of antibiotics as a growth factor and to overcome the shortcomings that may arise in the absence of antibiotics [7]. For this purpose, the aromatic plants, etheric oils obtained from these plants and their bioactive secondary metabolites are used in medicine, cosmetics and food fields due to their various properties including antibacterial, antioxidant, antiviral, antifungal and digestive stimulatory effect. They are gaining currency to be used as an animal nutrition as well [5]. In plant tissues, high molecular compounds like carbohydrate, lipid, protein, cellulose, lignin and pectin are quite abundant and these substances, called primary (main) metabolites, are necessary for physiological development of plants due to their primary role in cell metabolism [8]. On the other hand, secondary metabolites are produced from primary metabolites via biosynthesis and generally have role in pollination, complying with environmental conditions, chemical defense against microorganisms, insects and other predators and competition with other plants. They are small molecules, whose quantities are sometimes too low to be measured such as alkaloids, volatile oils, glycosides, steroids, flavonoids, tannins, phenols, coloring agent and resins $[9,10]$. The bioactive substances synthesized in medicinal and aromatic plants increase or decrease depending on the part of plant which is used as a drug, the physiological period of plant and the time when plant drug are gathered. This change results in difficulty in finding the effective dosage that makes harder use of plant itself or its essential oils directly as feed additive. Therefore, it is preferred to use active substances in the composition of the essential oil isolated from aromatic plants as feed additives [11]. In the experiment, as proportion of carvacrol found in thyme (Origanum vulgare) essential oil, cinnamaldehyde found in cinnamon (Cinnamomum zeylanicum) essential oils, capsaicin bioactive substances found in chili paprika (Capsicum annuum) can vary in etheric oils due to reasons mentioned above, synthetic 99\% carvactol, 98\% cinnamaldehyde, 99\% capsicum oleoresin (includes 6.6\% capsaicin), which are identical to natural secondary metabolites were used. Because carvacrol and cinnamaldehyde are both digestive stimulants and can increase appetite as well as being antifunfgal [11, 12], while capsicum oleoresin is endocrine and immune stimulant $[13,14]$, and also antioxidant [15], lastly the mixture group can act synergistically with various combination of active substances, they were preferred [16]. On the other hand, in studies conducted with different plant extracts and etheric oils, it was found that sensory (tenderness, taste) and physical (toughness, firmness) properties of broiler meat were not affected in general [17], and some of the chemical properties (decreased MDA, increased PUFA) were improved [18]. Indeed, The purpose of this study was to explore the effects of main active ingredients and homogeneous mixtures of carvacrol found in the essential oil of thyme (Origanum vulgare), cinnamaldehyde found in the essential oil of cinnamon (Cinnamomum zeylanicum) and capsicum oleoresin found in the extracts of hot red pepper (Capsicum annuum) on mixed feed at a rate of $150 \mathrm{mg} / \mathrm{kg}$ on the sensory, physical and chemical properties of broilers' breast meat (including pectoralis major and pectoralis minor) and leg meat (including thigh and drumstick).

\section{Materials and methods}

\section{Chicks, experimental design and diets}

A total of 400 male-female broiler chicks (Ross-308) were used as animal material. Experiments were carried out with 5 groups each containing 80 chicks: 4 treatment groups and 1 control group. Each group was further divided into 5 sub-groups each composed of 16 chicks. Among these five dietary treatment groups formed for the trial, the control group was fed without 
any feed additives. The second group was fed with $150 \mathrm{mg}$ capsicum oleoresin per $\mathrm{kg}$ of feed, the third group with $150 \mathrm{mg}$ carvacrol per $\mathrm{kg}$ of feed, the fourth group with $150 \mathrm{mg}$ cinnamaldehyde per $\mathrm{kg}$ of feed, and the last group with $150 \mathrm{mg}$ mixtures $(\mathrm{CAP}+\mathrm{CAR}+\mathrm{CIN})$ per $\mathrm{kg}$ of feed. The trial was maintained for 6 weeks. Feeds that were used in the experiments were obtained from a commercial feed factory (EGETAV, Izmir, Turkey). Rations were prepared in accordance with the nutrient requirements provided in NRC [19] (Table 1). Rations for each treatment group were prepared by adding $150 \mathrm{mg} / \mathrm{kg}$ each of capsicum oleoresin (CAP), carvacrol (CAR), cinnamaldehyde (CIN) or their mixture $(\mathrm{CAP}+\mathrm{CAR}+\mathrm{CIN})$. To ensure a homogeneous blend, secondary metabolites were pre-mixed with zeolite and the generated crumble was added to the feed. Commercially marketed synthetic 99\% carvacrol, $98 \%$ cinnamaldehyde and naturally produced $99 \%$ capsicum oleoresin and their combinations at a ratio of 1:1:1 were used. The amount of food substance of the feeds used (except for raw cellulose) was specified according to the Weende [20] method while the raw cellulose was specified according to the Lepper method [21]. The regression equation suggested by the 9610 No TSI was used for calculation of the metabolizable energy content [22].

\section{Sensory analysis}

For sensory analysis, meats were removed from deep freeze $24 \mathrm{~h}$ prior to use, thawed at $+4{ }^{\circ} \mathrm{C}$ and grilled. Panelists assessed the odor, tenderness, taste, juiciness, appearance and overall acceptability for grilled meat samples scoring from 1 to 5 . The assessors were selected and trained according to the international standards [23]. The sensory evaluation was performed according to a standardized sensory descriptive method [24].

\section{Physical analysis}

\section{Determination of color specification}

Colors of breast meat and leg meat were determined through measurements made by Minolta colorimeter (Minolta CR-300) in CIE $\mathrm{L}^{*}, \mathrm{a}^{*}, \mathrm{~b}^{*}$ categories. Measurements were made on 3 different parts of both types of meat. $L^{*}$ value indicated the lightness of the color, while $a^{*}$ value standed for redness and $b^{*}$ value for yellowness [25].

\section{Thawing loss}

Meat samples of breast and leg which had been weighed during slaughter were removed from deep freezer $\left(-20^{\circ} \mathrm{C}\right)$ and allowed to stand at $+4{ }^{\circ} \mathrm{C}$ overnight before being thawed. The difference between pre-frost and post-defrost weights was calculated as thawing loss [26].
Table 1 Ingredients and chemical composition of experimental diets (as-fed basis)

\begin{tabular}{|c|c|c|}
\hline Feed stuff, \% & $\begin{array}{l}\text { Broiler chick } \\
\text { (0-21. Days) }\end{array}$ & $\begin{array}{l}\text { Broiler } \\
\text { (22-42. Days) }\end{array}$ \\
\hline Corn & 46.96 & 48.91 \\
\hline Soybean meal & 20.88 & 12.37 \\
\hline Wheat & 0.00 & 5 \\
\hline Full-fat soybean & 14.57 & 15 \\
\hline Corn bran & 4.5 & 3 \\
\hline Sunflower seed meal 34\% CP & 4 & 4.5 \\
\hline DDGS & 2.5 & 3 \\
\hline Poultry meal & 2.29 & 4 \\
\hline Marble powder & 1.12 & 0.93 \\
\hline DCP $18 \%$ & 1.08 & 0.71 \\
\hline Lysine sulfate $70 \%$ & 0.51 & 0.46 \\
\hline Commercial fat & 0.5 & 1.15 \\
\hline Commercial methionine & 0.32 & 0.23 \\
\hline aVitamin premix-001 & 0.2 & 0.00 \\
\hline bitamin premix-002 & 0.00 & 0.2 \\
\hline Salt & 0.19 & 0.16 \\
\hline Sodium sulfate & 0.12 & 0.10 \\
\hline${ }^{\circ}$ Mineral & 0.10 & 0.1 \\
\hline L-threonine & 0.06 & 0.04 \\
\hline Liquid choline 75\% & 0.06 & 0.06 \\
\hline Coccidiostat & 0.05 & 0.05 \\
\hline \multicolumn{3}{|l|}{ Calculated values, g/kg } \\
\hline Metabolizable energy, kcal/kg & 3025 & 3150 \\
\hline Lysine & 14.57 & 12.72 \\
\hline Methionine + cystine & 10.97 & 9.99 \\
\hline Available P & 5.00 & 4.5 \\
\hline \multicolumn{3}{|l|}{ Composition (analyzed), g/kg } \\
\hline Dry matter & 880.29 & 880.85 \\
\hline Crude protein & 237.65 & 217.67 \\
\hline Ether extract & 56.96 & 66.06 \\
\hline Crude ash & 59.73 & 52.69 \\
\hline Crude fiber & 37.06 & 36.70 \\
\hline Calcium & 10.50 & 9.00 \\
\hline Total phosphorus & 6.40 & 5.69 \\
\hline Starch & 344.30 & 376.12 \\
\hline Sugar & 41.24 & 35.65 \\
\hline
\end{tabular}

Vitamin premix-001 per kg diet: 11000 IU Vitamin $A ; 5000$ IU Vitamin $D_{3}$. $0.069 \mathrm{mg} 25-\mathrm{OH}-\mathrm{D}_{3} ; 150 \mathrm{mg}$ Vitamin $\mathrm{E} ; 3 \mathrm{mg}$ Vitamin $\mathrm{K}_{3} ; 3 \mathrm{mg}$ Vitamin $\mathrm{B}_{1}$; $8 \mathrm{mg}$ Vitamin $B_{2} ; 4 \mathrm{mg}$ Vitamin $B_{6 ;} 0.02 \mathrm{mg}$ Vitamin $B_{12} ; 60 \mathrm{mg}$ Niacin; $15 \mathrm{mg}$ D-Pantothenic; $2 \mathrm{mg}$ Folic acid; $0.2 \mathrm{mg}$ Biotin; $100 \mathrm{mg}$ Vitamin C; $400 \mathrm{mg}$ choline,

${ }^{b}$ Vitamin premix-002 per kg diet: There are 10,000 IU Vitamin A; 5000 IU Vitamin $D_{3 ;} 0.069 \mathrm{mg} 25-\mathrm{OH}_{-} \mathrm{D}_{3} ; 50 \mathrm{mg}$ Vitamin $\mathrm{E}_{3} 3 \mathrm{mg}$ Vitamin $\mathrm{K}_{3} ; 3 \mathrm{mg}$ Vitamin $B_{1} ; 8 \mathrm{mg}$ Vitamin $B_{2 ;} 4$ mg Vitamin $B_{6} ; 0.02 \mathrm{mg}$ Vitamin $B_{12}$; $60 \mathrm{mg}$ Niacin; $12 \mathrm{mg}$ D-Pantothenic; $2 \mathrm{mg}$ Folic acid; $0.2 \mathrm{mg}$ Biotin; $100 \mathrm{mg}$ Vitamin C; $400 \mathrm{mg}$ choline,

'Mineral per kg diet: $150 \mathrm{~g} \mathrm{Mn}, 120 \mathrm{~g} \mathrm{Fe}, 150 \mathrm{~g} \mathrm{Zn}, 14 \mathrm{~g} \mathrm{Cu}, 0,4 \mathrm{~g} \mathrm{Co}, 3 \mathrm{~g}$ Se 


\section{Cooking loss}

Weighed breast and leg meats were cooked for $45 \mathrm{~min}$ in a water bath set at $70{ }^{\circ} \mathrm{C}$. After a short weighing period, they were weighed again after their moisture was removed. Hence, the cooking losses were calculated [27].

pH

$\mathrm{pH}$ values of the samples of breast and thigh meats were measured with a $\mathrm{pH}$ meter (Hanna, USA) at $15^{\text {th }}$ minute (pH 15) after slaughtering.

\section{Water holding capacity}

Samples of $0.5 \mathrm{~g}$ breast and leg meats were placed in aluminum foils between metal plates and their waterholding capacities were calculated by being left underwater at 130 bar pressure for $1 \mathrm{~min}$ [28].

\section{Texture analysis}

To detect cooking losses, samples of breast and leg meats were prepared in dimensions of $3 \mathrm{~cm} \times 1.5 \mathrm{~cm} \times 1 \mathrm{~cm}$ (length $\mathrm{x}$ width $\mathrm{x}$ thickness) and boiled in water. Later, these samples were tested on a TA-XT Plus Texture Analyzer (Stable Micro Systems, Godalming, England), in accordance with the procedures described by Malovrh et al. [29]. In the analysis, a Warner-Bratzler knife, load cell of $50 \mathrm{~kg}$ and cylindrical probe of $35 \mathrm{~mm}$ diameter were used to measure the toughness and firmness of the meat. Pre-test speed was fixed at $2 \mathrm{~mm} / \mathrm{s}$, test speed at $2 \mathrm{~mm} / \mathrm{s}$ and post-test speed at $10 \mathrm{~m} / \mathrm{s}$.

\section{Chemical analysis Lipid oxidation}

Level of malondialdehyde (MDA) as a measure of lipid oxidation in breast and leg meats were determined in accordance with the thiobarbituric acid (TBA) method reported by Witte et al. [30]. Spectrophotometer values of MDA were adjusted by a correction factor (7.8) to calculate milligrams per kilogram of meat [31].

\section{Meat Composition}

Composition of fatty acids in oil extractions taken from breast and leg meats were determined by an anonymous method [32]. To determine the fatty acid composition, crude fat of the breast and leg meats were extracted using a chloroform:methanol $(2: 1, \mathrm{vol} / \mathrm{vol})$ mixture according to the method described by Folch et al. [33]. Fatty acids were measured using an HP-6890 gas chromatograph (Hewlett Packard, Palo Alto, CA). The determination of nutrient composition, dry matter, crude ash, crude fat analysis of breast and leg meats (which had been homogenized by shredding), were carried out in accordance with the Weende analysis method [20]. The crude protein contents of breast and thigh meats were determined employing the method developed by
Kjeldahly [34]. The amount of nitrogen found as a result of the analysis was multiplied by the factor of 6.25 and the crude protein contents of the samples were found.

\section{Statistical analysis}

SPSS 21.0 [35] program was used for statistical analysis of the data. One-way analysis of variance (ANOVA) was applied to define the effect of the test on sensory, physical and chemical properties of the meat samples while a Duncan test was carried out to determine the difference between the means $(P<0.05)$.

\section{Results and discussion}

\section{Sensory analysis}

Group's average panel scores according to the flavor of the breast and leg meat are shown in Table 2. It was found out that there was no statistically significant difference in sensory characteristics between groups of breast meat $(P>0.05)$; and the differences were significant for groups of leg meat $(P<0.05)$. The mixed group had the best score in terms of taste, tenderness and juiciness. When literature was reviewed, it was seen that various aromatic compounds had different effects on chicken meat in terms of sensory properties and these effects changed in line with the dosage [36, 37]. Simsek et al. [6] reported that although blends of essential oil (thyme + anise + carnation) at different doses (100, 200 and $400 \mathrm{ppm})$ did not make any difference in sensory properties, essential oils could be used for antimicrobial use in broiler feeding, especially in adverse environmental conditions, and may have a positive effect on digestion. According to our experimental results, it is possible to say that addition of CAP+CAR+CIN at a dose of $150 \mathrm{mg} / \mathrm{kg}$ had a sensory synergistic effect and it improves taste, tenderness, juiciness and overall acceptability.

\section{Physical analysis}

In Table 3, the physical properties of the groups are shown. It was found out that the differences between the groups were statistically significant in terms of thawing, cooking losses and water holding capacity of breast and leg meat $(P<0.05)$. The lowest level of thawing loss was observed in CAR group for breast meat and in CAR and CIN groups for the leg meat while the lowest level of cooking loss was observed in the mixed group that is $\mathrm{CAP}+\mathrm{CAR}+\mathrm{CIN}$ for both breast and leg meats. The lowest level of water holding capacity was found in the CAP and control groups for breast meat, and in CAP group for leg meat $(P<0.05)$. The difference between the treatment groups and the control group was statistically insignificant in terms of $\mathrm{pH}$ levels $(P>0.05)$. When the literature on the subject was reviewed, it was seen that addition of essential oils whose main compounds are CAP, CAR or CIN in different ratios had, in general, no 
Table 2 Average panel scores according to the flavor of the breast and leg meat of the groups of broiler chicks fed with feed containing capsicum oleoresin, carvacrol, cinnamaldehyde and their mixtures (out of 5, x \pm SEM)

\begin{tabular}{|c|c|c|c|c|c|c|}
\hline & \multicolumn{5}{|c|}{ Treatment Groups } & \multirow[b]{2}{*}{$P$} \\
\hline & Control & CAP & CAR & CIN & $\mathrm{CAP}+\mathrm{CAR}+\mathrm{CIN}$ & \\
\hline \multicolumn{7}{|l|}{ Breast meat } \\
\hline Taste & $3.50 \pm 0.31$ & $3.90 \pm 0.31$ & $4.00 \pm 0.21$ & $3.70 \pm 0.30$ & $4.10 \pm 0.28$ & 0.712 \\
\hline Tenderness & $4.30 \pm 0.26$ & $4.10 \pm 0.57$ & $3.90 \pm 0.31$ & $4.00 \pm 0.21$ & $4.00 \pm 0.37$ & 0.873 \\
\hline Juiciness & $3.50 \pm 0.34$ & $3.70 \pm 0.34$ & $3.70 \pm 0.34$ & $3.30 \pm 0.37$ & $3.60 \pm 0.31$ & 0.911 \\
\hline Odor & $3.60 \pm 0.31$ & $3.50 \pm 0.31$ & $4.10 \pm 0.23$ & $3.70 \pm 0.37$ & $3.90 \pm 0.23$ & 0.614 \\
\hline Appearance & $4.10 \pm 0.35$ & $3.90 \pm 0.28$ & $3.70 \pm 0.34$ & $3.70 \pm 0.30$ & $4.60 \pm 0.22$ & 0.202 \\
\hline Overall acceptability & $3.90 \pm 0.18$ & $3.90 \pm 0.23$ & $4.10 \pm 0.18$ & $3.80 \pm 0.20$ & $4.22 \pm 0.28$ & 0.649 \\
\hline \multicolumn{7}{|l|}{ Leg meat } \\
\hline Taste & $3.67 \pm 0.24^{b}$ & $4.30 \pm 0.26^{b}$ & $4.10 \pm 0.28^{b}$ & $4.11 \pm 0.31^{b}$ & $5.00 \pm 0.00^{a}$ & 0.007 \\
\hline Tenderness & $4.75 \pm 0.16^{\mathrm{ab}}$ & $4.40 \pm 0.22^{b c}$ & $4.10 \pm 0.23^{c}$ & $4.30 \pm 0.21^{b c}$ & $5.00 \pm 0.00^{a}$ & 0.012 \\
\hline Juiciness & $4.40 \pm 0.17^{\mathrm{ab}}$ & $4.78 \pm 0.15^{\mathrm{ab}}$ & $4.00 \pm 0.27^{b}$ & $4.40 \pm 0.17^{\mathrm{ab}}$ & $4.90 \pm 0.10^{\mathrm{a}}$ & 0.006 \\
\hline Odor & $3.33 \pm 0.33$ & $4.13 \pm 0.35$ & $3.67 \pm 017$ & $3.60 \pm 0.31$ & $4.40 \pm 0.16$ & 0.052 \\
\hline Appearance & $4.44 \pm 0.24$ & $4.33 \pm 0.29$ & $3.70 \pm 0.26$ & $4.60 \pm 0.22$ & $4.50 \pm 0.27$ & 0.110 \\
\hline Overall acceptability & $3.90 \pm 0.23^{b}$ & $4.30 \pm 0.21^{b}$ & $4.30 \pm 0.26^{b}$ & $4.30 \pm 0.21^{b}$ & $5.00 \pm 0.00^{\mathrm{a}}$ & 0.026 \\
\hline
\end{tabular}

$a, b, c$ The differences between means in the same row with different letters are important, $P<0.05$

Sensory properties (taste, tenderness, juiciness, odor, appearance and overall acceptability) order $1=$ Worst, $5=$ Best

effect on the physical properties [38-40]. Elmali et al. [41] stated that the incompatibility of values observed in the study, such as $\mathrm{pH}$ levels, cooking loss, color, etc., could be due to the existence of different feeding programs. According to our results of the physical analysis, it can be concluded that the addition of CAR and CIN improves thawing loss in breast and leg meats, the addition of CAP+CAR+CIN improves the cooking loss, and the addition of CAP improves the water holding capacity.

The color properties of the groups are given in Table 4 . Accordingly, the addition CAP, CAR, CIN and CAP+CAR $+\mathrm{CIN}$ to the diet at a dose of $150 \mathrm{mg} / \mathrm{kg}$, did not affect the color ( $\mathrm{L}^{*}$-lightness, $\mathrm{a}^{*}$-redness, $\mathrm{b}^{*}$-yellowness) of breast meat, but addition of CAP increased the level of $L^{* *}$ value while addition of CIN decreased it $(P<0.05)$. Yetisir et al. [42] mentioned that increasing $L^{*}$ value was desirable in terms of acceptance by consumers. Although in our study the statistically highest $\mathrm{L}^{*}$ value was found in the CIN group, this fact was not supported by the findings of sensory analysis carried out to determine consumer acceptance. Nevertheless, the sensory characteristics of the mixed group which had an $\mathrm{L}^{*}$ value closest to the CIN group, were found to be more favorable.

The results of texture analysis for the groups were provided in Table 5 . When the groups were compared by the breast meats in terms of firmness, the highest value was found to be in the group with CIN supplement while the lowest value was found to be in the group with CAR supplement. In terms of toughness, no significant difference

Table 3 Effects of capsicum oleoresin, carvacrol, cinnamaldehyde and their mixtures added to broilers' mixed feed on thawing loss, cooking loss, water holding capacity and $\mathrm{pH}$ values of the breast and leg meat ( $\mathrm{x} \pm \mathrm{SEM}$ )

\begin{tabular}{|c|c|c|c|c|c|c|c|}
\hline & & \multicolumn{5}{|c|}{ Treatment Groups } & \multirow[b]{2}{*}{$P$} \\
\hline & & Control & CAP & CAR & $\mathrm{CIN}$ & $C A P+C A R+C I N$ & \\
\hline \multirow[t]{4}{*}{ Breast meat } & Thawing loss, $\%$ & $2.88 \pm 0.24^{c}$ & $2.26 \pm 0.27^{\mathrm{ab}}$ & $1.72 \pm 0.19^{a}$ & $2.20 \pm 0.16^{\mathrm{ab}}$ & $2.57 \pm 0.12^{\mathrm{bc}}$ & 0.000 \\
\hline & Cooking loss, $\%$ & $12.18 \pm 0.83^{b c}$ & $12.63 \pm 1.11^{b c}$ & $13.15 \pm 0.58^{c}$ & $9.85 \pm 0.52^{\mathrm{ab}}$ & $7.12 \pm 1.71^{\mathrm{a}}$ & 0.010 \\
\hline & Water holding capacity, \% & $50.26 \pm 1.31^{\mathrm{a}}$ & $49.37 \pm 1.19^{a}$ & $43.29 \pm 2.63^{b}$ & $43.20 \pm 0.90^{b}$ & $46.16 \pm 1.03^{\mathrm{ab}}$ & 0.010 \\
\hline & $\mathrm{pH}$ (15.min.) & $5.76 \pm 0.04$ & $5.74 \pm 0.05$ & $5.74 \pm 0.04$ & $5.72 \pm 0.06$ & $5.69 \pm 0.04$ & 0.823 \\
\hline \multirow[t]{4}{*}{ Leg meat } & Thawing loss, $\%$ & $1.63 \pm 0.19^{b}$ & $1.63 \pm 0.14^{b}$ & $0.95 \pm 0.14^{\mathrm{a}}$ & $1.03 \pm 0.16^{\mathrm{a}}$ & $1.31 \pm 0.12^{\mathrm{ab}}$ & 0.011 \\
\hline & Cooking loss, \% & $18.34 \pm 0.95^{\mathrm{b}}$ & $16.23 \pm 1.84^{\mathrm{b}}$ & $17.17 \pm 1.37^{b}$ & $15.79 \pm 1.01^{\mathrm{b}}$ & $10.49 \pm 1.39^{\mathrm{a}}$ & 0.024 \\
\hline & Water holding capacity, \% & $40.31 \pm 0.58^{c}$ & $46.24 \pm 0.90^{\mathrm{a}}$ & $43.76 \pm 0.76^{\mathrm{abc}}$ & $42.25 \pm 1.60^{\mathrm{bc}}$ & $44.76 \pm 1.95^{\mathrm{ab}}$ & 0.031 \\
\hline & $\mathrm{pH}$ (15.min.) & $5.88 \pm 0.05$ & $5.74 \pm 0.05$ & $5.84 \pm 0.06$ & $5.81 \pm 0.08$ & $5.78 \pm 0.06$ & 0.570 \\
\hline
\end{tabular}

\footnotetext{
$\mathrm{a}, \mathrm{b},{ }^{\mathrm{C}}$ The differences between means in the same row with different letters are important, $P<0.05$
} 
Table 4 Effects of capsicum oleoresin, carvacrol, cinnamaldehyde and their mixtures added to broilers' mixed feed on the color properties of the breast and leg meats $(x \pm$ SEM)

\begin{tabular}{|c|c|c|c|c|c|c|c|}
\hline & \multicolumn{6}{|c|}{ Treatment Groups } & \multirow[b]{2}{*}{$\mathrm{P}$} \\
\hline & Con & & CAP & CAR & $\mathrm{CIN}$ & $\mathrm{CAP}+\mathrm{CAR}+\mathrm{CIN}$ & \\
\hline \multirow[t]{3}{*}{ Breast meat } & $L^{*}$ & $51.27 \pm 0.80$ & $52.46 \pm 1.99$ & $52.23 \pm 0.99$ & $52.59 \pm 1.80$ & $49.98 \pm 1.19$ & 0.676 \\
\hline & $a^{*}$ & $5.97 \pm 0.86$ & $5.52 \pm 0.27$ & $5.10 \pm 0.62$ & $5.14 \pm 0.69$ & $5.52 \pm 0.88$ & 0.904 \\
\hline & $b^{*}$ & $8.77 \pm 0.29$ & $9.75 \pm 0.49$ & $8.58 \pm 0.73$ & $9.57 \pm 0.51$ & $9.95 \pm 0.68$ & 0.351 \\
\hline \multirow[t]{3}{*}{ Leg meat } & $L^{*}$ & $49.18 \pm 0.64^{\mathrm{abc}}$ & $51.06 \pm 1.31^{c}$ & $50.47 \pm 1.24^{b c}$ & $46.59 \pm 0.62^{a}$ & $47.79 \pm 0.61^{\mathrm{ab}}$ & 0.019 \\
\hline & $a^{*}$ & $6.65 \pm 0.49$ & $5.97 \pm 0.67$ & $6.53 \pm 0.47$ & $7.17 \pm 1.05$ & $6.32 \pm 0.39$ & 0.734 \\
\hline & $b^{*}$ & $8.53 \pm 0.80$ & $9.00 \pm 0.62$ & $9.56 \pm 0.47$ & $9.39 \pm 0.43$ & $9.39 \pm 0.64$ & 0.761 \\
\hline
\end{tabular}

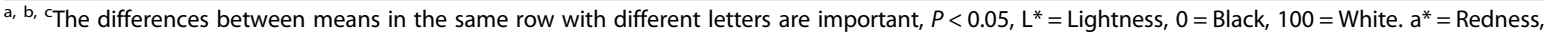
Negative values are green, positive values are red. $b^{*}=$ yellowness, Negative values are blue, positive values are yellow

was observed between groups $(P>0.05)$ except for the group with CAR supplement. On the other hand, in terms of firmness, the difference between treatment groups was found to be statistically insignificant $(P>0.05)$ while the highest value for toughness was found in the CAP+CAR $+\mathrm{CIN}$ group and the lowest level of toughness was observed in the control group. In the previous studies, it was reported that the results obtained from texture analysis of chicken meat were in line with the results of sensory or physical analysis (color, odor, taste, etc.) [43-45]. There is an inverse relationship between the firmness value obtained in textural analysis and the tenderness criterion in sensory analysis. However, the results obtained in the experiments indicated that there was no harmony between the firmness levels and tenderness values determined in the groups. Another relationship is between the value of toughness and the ratio of juiciness. The results obtained from the study show that the highest toughness value (in $\mathrm{CAP}+\mathrm{CAR}+\mathrm{CIN}$ treated group) and the best juiciness ratio (again in CAP $+\mathrm{CAR}+\mathrm{CIN}$ treated group) seem to correlate positively.

\section{Chemical analysis}

The nutrient compositions of the groups are shown in Table 6 . The results indicate that, the addition of the secondary metabolites to ration was effective on crude fat and crude ash levels in breast meat and dry matter as well as crude fat and crude ash levels in leg meat. The highest crude fat ratio for breast meat was found in CIN group, and for leg meat in the control group; the highest proportion of raw protein for breast meat was found in CAR group and for leg meat in CAP+CAR+CIN group. While there was no difference between the groups in terms of dry matter ratio in the breast meat, this ratio for leg meat was highest in CAR group. Kavouridou et al. [46] reported that $10 \%$ coconut, palm or flax seed oil extraction were not effective on the chemical composition of broiler chick and so did Fotea et al. [47] for additions of $0.1,0.3$ and $0.7 \%$ thyme oil extraction; and Kirkpinar et al. [37] for the additions of $300 \mathrm{mg}$ thyme, garlic, thyme+garlic. Duarte et al. [48] associated the ineffectiveness of 3.3, 6.6 and $9.9 \%$ of corn oil additions on $\mathrm{CF}$ of the chicken meat with the level of energy intake; and claimed that it could be due to the fact that the energy value of the feed had not changed.

In Table 7, lipid oxidation values for the groups on day 1 , day 4 and day 8 are presented. It was observed that the effects of the addition of CAP, CAR, CIN or CAP $+\mathrm{CAR}+\mathrm{CIN}$ at a dose of $150 \mathrm{mg} / \mathrm{kg}$ on the lipid oxidation in breast and leg meat on day 1 , day 4 and day 8 were not statistically significant compared to control group $(P>0.05)$. Symeon et al. [40] reported that the addition of $0.5-1.0 \mathrm{~mL} / \mathrm{kg}$ of cinnamon oil had no effect on MDA level in the pectoralis major muscles taken from chicks on days 1, 3, 5 and 9 as well as in the 4th, 5th and 6th months. Luna et al. [49] stated that addition of $150 \mathrm{mg} / \mathrm{kg}$ thymol and $150 \mathrm{mg} / \mathrm{kg}$ carvacrol improves MDA values in breast and leg meat. They claimed that this effect for breast meat was more prominent on day 5,

Table 5 Effects of capsicum oleoresin, carvacrol, cinnamaldehyde and their mixtures added to broilers' mixed feed on the texture properties of the breast and leg meat $(x \pm$ SEM)

\begin{tabular}{|c|c|c|c|c|c|c|c|}
\hline & & \multicolumn{5}{|c|}{ Treatment Groups } & \multirow[b]{2}{*}{$P$} \\
\hline & & Control & CAP & CAR & $\mathrm{CIN}$ & $C A P+C A R+C I N$ & \\
\hline \multirow[t]{2}{*}{ Breast meat } & Firmness (kg) & $2.00 \pm 0.14^{\mathrm{bc}}$ & $1.98 \pm 0.19^{b c}$ & $2.38 \pm 0.14^{c}$ & $1.55 \pm 0.09^{a}$ & $1.79 \pm 0.15^{\mathrm{ab}}$ & 0.000 \\
\hline & Toughness (kg) & $11.09 \pm 0.74^{a}$ & $11.09 \pm 0.79^{a}$ & $14.31 \pm 0.86^{b}$ & $9.32 \pm 0.48^{\mathrm{a}}$ & $9.46 \pm 0.82^{\mathrm{a}}$ & 0.000 \\
\hline \multirow[t]{2}{*}{ Leg meat } & Firmness (kg) & $2.29 \pm 0.14$ & $1.89 \pm 0.30$ & $1.75 \pm 0.15$ & $1.50 \pm 0.15$ & $1.67 \pm 0.08$ & 0.166 \\
\hline & Toughness (kg) & $16.56 \pm 1.59^{c}$ & $15.90 \pm 1.48^{b c}$ & $14.97 \pm 1.04^{\mathrm{abc}}$ & $12.87 \pm 1.51^{\mathrm{ab}}$ & $11.24 \pm 0.75^{\mathrm{a}}$ & 0.008 \\
\hline
\end{tabular}

$\mathrm{a}, \mathrm{b}, \mathrm{c}$ The differences between means in the same row with different letters are important, $P<0.05$ 
Table 6 Effects of capsicum oleoresin, carvacrol, cinnamaldehyde and their mixtures added to broilers' mixed feed on the nutrient compositions of the breast and leg meat $(x \pm$ SEM)

\begin{tabular}{|c|c|c|c|c|c|c|c|}
\hline & & \multicolumn{5}{|c|}{ Treatment Groups } & \multirow[b]{2}{*}{$P$} \\
\hline & & Control & CAP & CAR & $\mathrm{CIN}$ & $C A P+C A R+C I N$ & \\
\hline \multirow[t]{4}{*}{ Breast meat } & Dry matter, $\%$ & $26.57 \pm 0.25$ & $26.28 \pm 0.26$ & $26.68 \pm 0.17$ & $26.37 \pm 0.28$ & $26.89 \pm 0.26$ & 0.424 \\
\hline & Crude ash,\% & $0.95 \pm 0.10$ & $1.20 \pm 0.04$ & $1.07 \pm 0.07$ & $1.15 \pm 0.06$ & $1.10 \pm 0.07$ & 0.097 \\
\hline & Crude fat, $\%$ & $0.66 \pm 0.09^{a}$ & $0.26 \pm 0.03^{b}$ & $0.35 \pm 0.04^{b}$ & $0.73 \pm 0.06^{\mathrm{a}}$ & $0.36 \pm 0.08^{b}$ & 0.000 \\
\hline & Crude protein,\% & $24.93 \pm 0.26^{b c}$ & $25.02 \pm 0.25^{b c}$ & $27.61 \pm 1.00^{\mathrm{a}}$ & $23.95 \pm 0.23^{c}$ & $25.41 \pm 0.32^{b}$ & 0.000 \\
\hline \multirow[t]{4}{*}{ Leg meat } & Dry matter, $\%$ & $23.34 \pm 0.27^{b}$ & $24.26 \pm 0.35^{b}$ & $25.86 \pm 0.61^{a}$ & $23.93 \pm 0.71^{b}$ & $24.23 \pm 0.45^{b}$ & 0.009 \\
\hline & Crude ash,\% & $1.06 \pm 0.06$ & $0.93 \pm 0.04$ & $1.03 \pm 0.04$ & $1.04 \pm 0.03$ & $1.07 \pm 0.05$ & 0.140 \\
\hline & Crude fat, $\%$ & $0.80 \pm 0.06^{\mathrm{a}}$ & $0.48 \pm 0.08^{b c}$ & $0.65 \pm 0.08^{\mathrm{ab}}$ & $0.55 \pm 0.08^{b}$ & $0.28 \pm 0.05^{c}$ & 0.000 \\
\hline & Crude protein,\% & $21.10 \pm 0.25^{b}$ & $20.41 \pm 0.28^{b}$ & $21.23 \pm 0.44^{b}$ & $21.41 \pm 0.35^{b}$ & $23.52 \pm 0.76^{\mathrm{a}}$ & 0.001 \\
\hline
\end{tabular}

$\mathrm{a}, \mathrm{b}, \mathrm{c}$ The differences between means in the same row with different letters are important, $P<0.05$

partial on day 10, and for leg meat it is partial on day 5 and more prominent on day 10. Ciftci et al. [18] stated that addition of $1000 \mathrm{ppm}$ cinnamon oil improved MDA value relative to control group, which could be due to antioxidant property of cinnamon oil. Faix et al. [50] associated the fact that the addition of $250 \mathrm{ppm}$ $1000 \mathrm{ppm}$ cinnamon oil reduced the MDA level in the blood serum to the reduction of lipid oxidation through increase of hepatic antioxidant enzyme activities (glutathioneeproxidase, superoxidedismutase, catalase, gamma-glutamyltransferase, etc.). Regarding the secondary metabolites that make up the working material, Kim et al. [51] and Lillehoj et al. [52] reported that they were effective on antibacterial activity and on lipid metabolism. According to the results of our study, CAP, CAR and CIN generally affected lipid oxidation in samples taken from breast and leg meats, but this effect did not appear statistically significant. However, it is the combination of CAP+CAR $+\mathrm{CIN}$ that most positively affected lipid oxidation in both breast and leg meat although this effect remained at just numerical level.

In Table 8, the fat compositions of the breast meat in different groups are illustrated. Expectedly, the difference between the groups was found to be statistically significant for linoleic, eicosanoid, linolenic and lignoseric acids $(P<0.05)$. When the groups were evaluated for total fatty acid contents of breast meat and $\Sigma \mathrm{n}-3, \Sigma \mathrm{n}-6 \sum \mathrm{n}-9$ fatty acids, it was found out that the difference between total monounsaturated fatty acids (MUFA) and $\Sigma \mathrm{n}-3$ fatty acids was statistically significant $(P<0.05)$ while the difference between total saturated (SFA), unsaturated (UFA), polyunsaturated (PUFA), $\Sigma \mathrm{n}-6$ and $\Sigma$ n-9 fatty acids was not statistically significant $(P>0$. 05). Highest ratio for $\Sigma$ MUFA was observed in CAR group while values for eicosanoid, eicosapentaenoic acid (EPA), lignoseric and $\Sigma \mathrm{n}-3$ fatty acids were found to be highest in $\mathrm{CAP}+\mathrm{CAR}+\mathrm{CIN}$ group. Bolukbasi et al. [53] reported that adding 100 and $200 \mathrm{mg} / \mathrm{kg}$ of thyme oil to the feed decreased the ratio of $\Sigma$ SFA while the same addition increased $\Sigma$ MUFA and $\Sigma$ PUFA ratios in breast meat. Ciftci et al. [18] reported that the addition of $500 \mathrm{ppm}$ and $1000 \mathrm{ppm}$ cinnamon oil to the broilers' ration reduced the ratio of $\Sigma$ SFA but significantly increased the ratio of $\Sigma \mathrm{n}-3$ and $\Sigma \mathrm{n}-6$ fatty acids, without any affect on $\Sigma$ MUFA in breast meat. Shin et al. [54] reported that addition of conjugated linoleic acid, flaxseed oil or fish oil at a rate of $2 \%$ in ration of broiler chickens decreased PUFA while

Table 7 Effects of capsicum oleoresin, carvacrol, cinnamaldehyde and their mixtures added to broilers' mixed feed on the lipid oxidation of the breast and leg meat $(x \pm$ SEM)

\begin{tabular}{|c|c|c|c|c|c|c|c|}
\hline & & \multicolumn{5}{|c|}{ Treatment Groups } & \multirow[b]{2}{*}{$P^{*}$} \\
\hline & & Control & CAP & CAR & $\mathrm{CIN}$ & $C A P+C A R+C I N$ & \\
\hline \multirow[t]{3}{*}{ Breast meat } & 1.day & $0.45 \pm 0.07$ & $0.43 \pm 0.05$ & $0.39 \pm 0.04$ & $0.36 \pm 0.03$ & $0.29 \pm 0.03$ & 0.193 \\
\hline & 4.day & $0.47 \pm 0.06$ & $0.44 \pm 0.07$ & $0.45 \pm 0.06$ & $0.70 \pm 0.10$ & $0.33 \pm 0.08$ & 0.700 \\
\hline & 8.day & $0.85 \pm 0.26$ & $0.91 \pm 0.47$ & $0.77 \pm 0.40$ & $0.76 \pm 0.17$ & $0.73 \pm 0.18$ & 0.165 \\
\hline \multirow[t]{3}{*}{ Leg meat } & 1.day & $0.57 \pm 0.13$ & $0.63 \pm 0.10$ & $0.49 \pm 0.05$ & $0.60 \pm 0.10$ & $0.39 \pm 0.03$ & 0.553 \\
\hline & 4.day & $0.80 \pm 0.13$ & $0.74 \pm 0.10$ & $0.64 \pm 0.06$ & $0.70 \pm 0.10$ & $0.43 \pm 0.01$ & 0.157 \\
\hline & 8.day & $0.99 \pm 0.26$ & $0.87 \pm 0.51$ & $0.74 \pm 0.46$ & $0.74 \pm 0.08$ & $0.68 \pm 0.18$ & 0.930 \\
\hline
\end{tabular}


Table 8 Effects of capsicum oleoresin, carvacrol, cinnamaldehyde and their mixtures added to broilers' mixed feed on the composition of fatty acids in the breast meat ( $\mathrm{x} \pm \mathrm{SEM}$ )

\begin{tabular}{|c|c|c|c|c|c|c|}
\hline \multirow[b]{2}{*}{ Fatty acids of breast meat ${ }^{1}$} & \multicolumn{5}{|c|}{ Treatment Groups } & \multirow[b]{2}{*}{$P$} \\
\hline & Control & CAP & CAR & $\mathrm{CIN}$ & $\mathrm{CAP}+\mathrm{CAR}+\mathrm{CIN}$ & \\
\hline$\overline{C_{12: 0} \text { Lauric }}$ & $0.05 \pm 0.03$ & $0.22 \pm 0.18$ & $0.15 \pm 0.11$ & $0.03 \pm 0.03$ & $0.31 \pm 0.15$ & 0.291 \\
\hline$C_{14: 0}$ Myristic & $0.28 \pm 0.08$ & $0.72 \pm 0.36$ & $0.64 \pm 0.18$ & $0.21 \pm 0.10$ & $0.39 \pm 0.04$ & 0.121 \\
\hline$C_{16: 0}$ Palmitic & $18.65 \pm 0.57$ & $13.20 \pm 6.22$ & $18.36 \pm 0.17$ & $17.69 \pm 0.71$ & $17.50 \pm 0.57$ & 0.312 \\
\hline$C_{16: 1}$ Palmitoleic & $1.82 \pm 0.27$ & $1.61 \pm 0.26$ & $3.27 \pm 0.93$ & $1.89 \pm 0.38$ & $1.85 \pm 0.27$ & 0.254 \\
\hline$C_{17: 0}$ Margaric & $0.53 \pm 0.04$ & $0.27 \pm 0.14$ & $0.48 \pm 0.13$ & $0.53 \pm 0.46$ & $0.42 \pm 0.12$ & 0.973 \\
\hline$C_{17: 1}$ Heptadecenoic & $0.00 \pm 0.00$ & $0.10 \pm 0.1$ & $0.05 \pm 0.05$ & $0.91 \pm 0.91$ & $0.40 \pm 0.32$ & 0.662 \\
\hline$C_{18: 0}$ Stearic & $6.78 \pm 0.29$ & $7.24 \pm 0.60$ & $6.32 \pm 0.22$ & $5.65 \pm 0.63$ & $5.86 \pm 0.45$ & 0.191 \\
\hline$C_{18: 1 n-9}$ Oleic & $30.09 \pm 0.00$ & $28.22 \pm 0.26$ & $30.27 \pm 1.21$ & $29.07 \pm 0.98$ & $28.78 \pm 0.67$ & 0.582 \\
\hline$C_{18: 3 n-6}$ Linoleic & $37.26 \pm 1.17^{\mathrm{a}}$ & $37.38 \pm 1.05^{a}$ & $34.86 \pm 0.76^{\mathrm{ab}}$ & $37.93 \pm 0.90^{\mathrm{a}}$ & $33.07 \pm 1.68^{b}$ & 0.030 \\
\hline$C_{18: 3 n-6}$ Translinoleic & $0.00 \pm 0.00$ & $0.15 \pm 0.15$ & $0.07 \pm 0.03$ & $0.09 \pm 0.09$ & $0.01 \pm 0.01$ & 0.560 \\
\hline$C_{20: 0}$ Arachidonic & $1.25 \pm 0.66$ & $0.04 \pm 0.04$ & $0.55 \pm 0.39$ & $1.19 \pm 0.53$ & $0.34 \pm 0.30$ & 0.402 \\
\hline$C_{20: 1}$ Eicosanoid & $0.06 \pm 0.06^{b}$ & $0.12 \pm 0.1^{b}$ & $0.15 \pm 0.1^{b}$ & $0.01 \pm 0.00^{b}$ & $0.87 \pm 0.34^{\mathrm{a}}$ & 0.006 \\
\hline$C_{20: 1 n-9}$ Linolenic & $0.90 \pm 0.55$ & $2.25 \pm 0.25$ & $1.80 \pm 0.36$ & $0.95 \pm 0.45$ & $1.61 \pm 0.42$ & 0.263 \\
\hline$C_{20: 1 n-9}$ Translinolenic & $0.31 \pm 0.10$ & $0.26 \pm 0.15$ & $0.14 \pm 0.07$ & $0.14 \pm 0.07$ & $0.38 \pm 0.26$ & 0.641 \\
\hline$C_{20: 5 n-3} E P A$ & $0.00 \pm 0.00^{b}$ & $0.00 \pm 0.00^{b}$ & $0.01 \pm 0.01^{b}$ & $0.03 \pm 0.01^{b}$ & $0.78 \pm 0.41^{\mathrm{a}}$ & 0.030 \\
\hline$C_{20: 6 n-3} \mathrm{DHA}$ & $0.58 \pm 0.22$ & $0.15 \pm 0.1$ & $0.05 \pm 0.05$ & $0.08 \pm 0.05$ & $1.07 \pm 0.61$ & 0.050 \\
\hline$C_{22: 0}$ Behenic & $1.58 \pm 0.17$ & $1.73 \pm 0.13$ & $0.14 \pm 0.27$ & $2.67 \pm 0.99$ & $2.02 \pm 0.13$ & 0.352 \\
\hline$C_{22: 5 n-3}$ DPA & $0.00 \pm 0.00$ & $0.00 \pm 0.00$ & $0.12 \pm 0.07$ & $0.00 \pm 0.00$ & $0.09 \pm 0.09$ & 0.701 \\
\hline$C_{24: 0}$ Lignoseric & $0.48 \pm 0.32^{b}$ & $0.41 \pm 0.21^{b}$ & $0.42 \pm 0.22^{b}$ & $0.12 \pm 0.08^{b}$ & $1.36 \pm 0.17^{\mathrm{a}}$ & 0.005 \\
\hline$C_{24: 1 n-9}$ Nervonic & $0.47 \pm 0.39$ & $0.11 \pm 0.07$ & $0.22 \pm 0.18$ & $0.23 \pm 0.36$ & $0.93 \pm 0.36$ & 0.330 \\
\hline$\sum S F A$ & $29.60 \pm 1.21$ & $30.82 \pm 0.79$ & $28.07 \pm 0.73$ & $28.10 \pm 0.76$ & $28.13 \pm 0.70$ & 0.331 \\
\hline$\sum$ UFA & $69.73 \pm 1.15$ & $70.06 \pm 1.61$ & $70.94 \pm 0.56$ & $71.10 \pm 1.01$ & $69.21 \pm 1.84$ & 0.758 \\
\hline$\sum M U F A$ & $31.14 \pm 0.45^{b c}$ & $30.15 \pm 0.48^{c}$ & $33.97 \pm 0.69^{a}$ & $32.11 \pm 0.54^{\mathrm{abc}}$ & $32.08 \pm 0.60^{\mathrm{ab}}$ & 0.005 \\
\hline$\sum$ PUFA & $37.29 \pm 1.78$ & $39.90 \pm 1.17$ & $36.97 \pm 0.73$ & $38.99 \pm 1.02$ & $36.41 \pm 1.94$ & 0.455 \\
\hline$\sum n-3$ & $1.96 \pm 0.37^{b}$ & $2.53 \pm 0.13^{\mathrm{ab}}$ & $2.53 \pm 0.23^{\mathrm{ab}}$ & $1.90 \pm 0.35^{b}$ & $3.67 \pm 0.59^{a}$ & 0.039 \\
\hline$\sum n-6$ & $37.45 \pm 0.27$ & $37.38 \pm 1.05$ & $35.57 \pm 0.35$ & $37.93 \pm 0.90$ & $35.14 \pm 1.79$ & 0.257 \\
\hline$\sum n-9$ & $30.56 \pm 1.15$ & $28.33 \pm 0.27$ & $30.50 \pm 1.05$ & $29.31 \pm 0.95$ & $29.68 \pm 0.64$ & 0.581 \\
\hline
\end{tabular}

$a, b$, $T$ The differences between means in the same row with different letters are important, $P<0.05$

${ }^{1}$ Breast meat in \% fatty acid

increasing $\Sigma$ n-3 and $\Sigma$ n-6 levels. Sadeghi et al. [55] reported that addition of fish oil, instead of corn, to the ration at a rate of $5 \%$ did not affect SFA, MUFA, PUFA, but decreased $\Sigma$ n- 6 and increased EPA and $\Sigma$ n-3 levels in breast meat.

In Table 9, the fat compositions of the leg meat in different groups are presented. The differences found for linoleic, EPA and behenic fatty acids are statistically important $(P<0.05)$. When the groups were evaluated according to their total fatty acid content and $\Sigma \mathrm{n}-3, \Sigma \mathrm{n}-6$ $\Sigma$ n-9 fatty acid levels in leg meat, it was determined that the differences between groups in terms of MUFA, PUFA and $\Sigma \mathrm{n}-6$ fatty acid levels were statistically significant $(P<0.05)$ while differences in terms of SFA, UFA, $\Sigma$ n-3 and $\Sigma$ n-9 fatty acids were not statistically significant $(P>0.05)$. The highest $\Sigma$ MUFA ratio was found in
$\mathrm{CAP}+\mathrm{CAR}+\mathrm{CIN}$ group while the highest $\Sigma \mathrm{PUFA}$ ratio was observed both in CAP and control groups. $\Sigma$ n-6 fatty acids values were at highest levels in CAP group. Bolukbasi et al. [53] reported that the addition of $100 \mathrm{mg} / \mathrm{kg}$ and $200 \mathrm{mg} / \mathrm{kg}$ of thyme oil to the feed lowered the ratio of $\Sigma$ SFA in comparison to the control group, while the ratio of $\Sigma$ PUFA increased in line with the dosage. Shin et al. [54] reported that addition of conjugated linoleic acid, linseed oil or fish oil to the ration at a rate of $2 \%$ decreased MUFA level in leg meat while increasing PUFA and $\Sigma \mathrm{n}-3$ values in comparison with the control group. Sadeghi et al. [55] reported that addition of fish oil instead of corn at a rate of $5 \%$ to the ration at different weeks $(2,3,4,5$ and 6$)$ increased SFA and $\Sigma \mathrm{n}-3$ in leg meat in 4 th week in comparison to control group, reduced $\Sigma \mathrm{n}-6$ ratio but did not change 
Table 9 Effects of capsicum oleoresin, carvacrol, cinnamaldehyde and their mixtures added to broilers' mixed feed on the composition of fatty acids in leg meat ( $x \pm$ SEM)

\begin{tabular}{|c|c|c|c|c|c|c|}
\hline \multirow[b]{2}{*}{ Fatty acids of leg meat ${ }^{1}$} & \multicolumn{5}{|c|}{ Treatment Groups } & \multirow[b]{2}{*}{$P$} \\
\hline & Control & CAP & CAR & $\mathrm{CIN}$ & $\mathrm{CAP}+\mathrm{CAR}+\mathrm{CIN}$ & \\
\hline$C_{12: 0}$ Lauric & $0.18 \pm 0.15$ & $0.08 \pm 0.03$ & $0.22 \pm 0.11$ & $0.34 \pm 0.27$ & $0.07 \pm 0.03$ & 0.688 \\
\hline$C_{14: 0}$ Myristic & $0.35 \pm 0.01$ & $0.39 \pm 0.05$ & $0.47 \pm 0.05$ & $0.60 \pm 0.21$ & $0.53 \pm 0.14$ & 0.645 \\
\hline$C_{16: 0}$ Palmitic & $15.10 \pm 4.34$ & $12.20 \pm 4.61$ & $18.77 \pm 0.94$ & $16.67 \pm 0.29$ & $18.20 \pm 0.38$ & 0.312 \\
\hline$C_{16: 1}$ Palmitoleic & $1.29 \pm 0.65$ & $1.93 \pm 0.02$ & $2.10 \pm 0.56$ & $2.29 \pm 0.47$ & $2.87 \pm 0.03$ & 0.317 \\
\hline$C_{17: 0}$ Margaric & $0.19 \pm 0.1$ & $0.35 \pm 0.13$ & $0.39 \pm 0.07$ & $0.70 \pm 0.39$ & $0.72 \pm 0.52$ & 0.749 \\
\hline$C_{17: 1}$ Heptadecenoic & $0.04 \pm 0.04$ & $0.07 \pm 0.04$ & $0.05 \pm 0.02$ & $0.02 \pm 0.02$ & $0.06 \pm 0.02$ & 0.730 \\
\hline$C_{18: 0}$ Stearic & $4.36 \pm 2.18$ & $5.87 \pm 0.33$ & $4.32 \pm 1.12$ & $5.55 \pm 4.65$ & $5.50 \pm 0.21$ & 0.817 \\
\hline$C_{18: 1 n-9}$ Oleic & $32.31 \pm 2.58$ & $28.40 \pm 0.07$ & $31.95 \pm 1.82$ & $29.83 \pm 0.84$ & $32.23 \pm 0.30$ & 0.515 \\
\hline$C_{18: 3 n-6}$ Linoleic & $37.45 \pm 0.27^{b c}$ & $40.22 \pm 1.02^{a}$ & $36.21 \pm 0.72^{\mathrm{bc}}$ & $37.97 \pm 1.28^{\mathrm{ab}}$ & $34.98 \pm 0.58^{c}$ & 0.014 \\
\hline$C_{18: 3 n-6}$ Translinoleic & $0.12 \pm 0.12$ & $0.00 \pm 0.00$ & $0.01 \pm 0.01$ & $0.06 \pm 0.06$ & $0.01 \pm 0.01$ & 0.523 \\
\hline$C_{20: 0}$ Arachidonic & $0.72 \pm 0.72$ & $1.10 \pm 1.07$ & $1.36 \pm 0.54$ & $1.48 \pm 0.67$ & $1.12 \pm 0.54$ & 0.939 \\
\hline$C_{20: 1}$ Eicosanoid & $0.31 \pm 0.27$ & $0.02 \pm 0.02$ & $0.15 \pm 0.04$ & $0.27 \pm 0.11$ & $0.21 \pm 0.05$ & 0.617 \\
\hline$C_{20: 1 n-9}$ Linolenic & $1.45 \pm 0.73$ & $1.23 \pm 1.23$ & $0.94 \pm 0.58$ & $0.77 \pm 0.77$ & $1.10 \pm 0.63$ & 0.973 \\
\hline$C_{20: 1 n-9}$ Translinolenic & $0.05 \pm 0.05$ & $0.22 \pm 0.00$ & $0.05 \pm 0.03$ & $0.19 \pm 0.03$ & $0.17 \pm 0.09$ & 0.143 \\
\hline$C_{20: 5 n-3} E P A$ & $0.01 \pm 0.01^{b}$ & $0.00 \pm 0.00^{b}$ & $0.32 \pm 0.10^{a}$ & $0.43 \pm 0.10^{a}$ & $0.02 \pm 0.01^{b}$ & 0.001 \\
\hline$C_{20: 6 n-3} \mathrm{DHA}$ & $0.19 \pm 0.10$ & $0.22 \pm 0.02$ & $0.25 \pm 0.10$ & $0.50 \pm 0.29$ & $0.23 \pm 0.12$ & 0.654 \\
\hline$C_{22: 0}$ Behenic & $1.74 \pm 0.00^{\mathrm{a}}$ & $1.65 \pm 0.06^{\mathrm{a}}$ & $1.80 \pm 0.06^{\mathrm{a}}$ & $1.14 \pm 0.06^{\mathrm{b}}$ & $1.20 \pm 0.06^{b}$ & 0.001 \\
\hline$C_{22: 5 n-3}$ DPA & $0.00 \pm 0.00$ & $0.00 \pm 0.00$ & $0.29 \pm 0.19$ & $0.42 \pm 0.26$ & $0.27 \pm 0.16$ & 0.527 \\
\hline$C_{24: 0}$ Lignoseric & $0.41 \pm 0.30$ & $0.42 \pm 0.09$ & $0.41 \pm 0.17$ & $0.26 \pm 0.13$ & $0.42 \pm 0.05$ & 0.964 \\
\hline$C_{24: 1 n-9}$ Nervonic & $0.24 \pm 0.24$ & $0.07 \pm 0.07$ & $0.28 \pm 0.15$ & $0.39 \pm 0.25$ & $0.12 \pm 0.05$ & 0.748 \\
\hline$\Sigma S F A$ & $26.17 \pm 1.19$ & $26.22 \pm 0.13$ & $27.38 \pm 0.38$ & $26.38 \pm 0.40$ & $27.76 \pm 0.80$ & 0.240 \\
\hline$\Sigma U F A$ & $73.29 \pm 0.86$ & $72.14 \pm 0.15$ & $72.46 \pm 0.39$ & $72.75 \pm 0.72$ & $72.13 \pm 0.45$ & 0.578 \\
\hline ¿MUFA & $32.53 \pm 0.49^{b c}$ & $30.48 \pm 0.02^{b}$ & $33.54 \pm 0.80^{a b}$ & $32.80 \pm 1.10^{b c}$ & $35.54 \pm 0.71^{a}$ & 0.004 \\
\hline ¿PUFA & $39.10 \pm 0.87^{a}$ & $41.65 \pm 0.13^{a}$ & $38.62 \pm 0.71^{b}$ & $38.39 \pm 1.41^{b}$ & $36.59 \pm 0.69^{b}$ & 0.008 \\
\hline$\sum n-3$ & $1.65 \pm 0.69$ & $1.45 \pm 0.72$ & $1.62 \pm 0.90$ & $1.98 \pm 0.88$ & $1.61 \pm 0.88$ & 0.996 \\
\hline$\sum n-6$ & $37.45 \pm 0.27^{b}$ & $40.22 \pm 0.59^{a}$ & $36.21 \pm 0.72^{b c}$ & $37.97 \pm 1.28^{\mathrm{ab}}$ & $34.98 \pm 0.58^{c}$ & 0.001 \\
\hline$\sum n-9$ & $32.55 \pm 2.42$ & $28.46 \pm 0.00$ & $32.35 \pm 1.70$ & $30.22 \pm 0.61$ & $32.41 \pm 0.30$ & 0.275 \\
\hline
\end{tabular}

$a, b$, $T$ The differences between means in the same row with different letters are important, $P<0.05$

${ }^{1}$ Leg meat in \% fatty acid

MUFA and PUFA values. $\Sigma$ MUFA and $\Sigma$ PUFA are required to be taken with food as $\Sigma$ MUFA is an HDL (High Density Lipoprotein) enhancer with beneficial effects on health, and $\Sigma$ PUFA has positive effects on some body functions and blood. The results obtained through our study indicated that addition of CAR increased $\Sigma$ MUFA ratio in the breast meat; addition of CAR, CIN, $\mathrm{CAP}+\mathrm{CAR}+\mathrm{CIN}$ decreased $\Sigma \mathrm{PUFA}$ ratio in the breast meat; and addition of CAP did not change the values in the breast meat and it did not have any effect at all on the leg meat. On the other hand, omega fatty acids, which are not synthesized in the body, are required to be consumed with nutrients because of their positive effects on brain development, strengthening the immune system and prevention of heart diseases [56, 57]. The results of our study revealed that omega fatty acids in breast meat and leg meat in treatment groups were positively affected. Accordingly, it was determined that the addition of CAP, CAR, CIN or CAP+CAR $+\mathrm{CIN}$ to the ration at a rate of $150 \mathrm{mg} / \mathrm{kg}$ changed the profile of fatty acids positively in broiler chickens, with different effect levels on their accumulation in breast meat and leg meat.

\section{Conclusion}

In conclusion, after the prohibition of antibiotics in poultry nutrition, research on the potential use of natural supplements has been accelerated in order to improve the performance and meat quality. In this study, the effects of dietary supplementation of the main active ingredients of different essential oils and extracts on sensory, physical and chemical properties of breast meat 
and leg meat were investigated. Consequently, it was determined that addition of CAP, CAR, CIN or CAP+CAR $+\mathrm{CIN}$ at a rate of $150 \mathrm{mg} / \mathrm{kg}$ affected the sensory properties of taste, tenderness, juiciness and overall acceptability; the physical properties of $\mathrm{L}^{*}$ value and toughness; and chemical properties of DM, CF, CP, linoleic, EPA, behenic, MUFA, PUFA, $\Sigma \mathrm{n}-6$ of the breast meat. Supplementation of these components also affected the physical properties of toughness and firmness as well as the chemical properties of $\mathrm{CF}, \mathrm{CP}$, linoleic, eicosanoid, EPA, lignoseric, MUFA and $\Sigma \mathrm{n}-3$ of the leg meat. Furthermore, while the treatments had a positive effect on both breast meat and leg meat with respect to thawing loss, cooking loss and water holding capacity; no effects were observed over $\mathrm{pH}$ value and lipid oxidation on day 1 , day 4 and day 8 . The results of the study indicated that addition of CAP, CAR, CIN or CAP+CAR+CIN to the ration improves the quality of the meat. However, the overall results suggest using mixtures of active ingredients to achieve the best effect in practice.

\section{Abbreviations \\ [n-3: Total Omega-3 Fatty Acids; $\sum n-6:$ Total Omega-6 Fatty Acids; ${ }^{\circ}$ C: Centigrade; $a^{*}$ : Redness; b*: Yellowness; CAP: Capsicum oleoresin; CAR: Carvacrol; CF: Crude Fat; CIN: Cinnamaldehyde; CP: Crude Protein; D: Dry Matter; EPA: Eicosapentaenoic Acid; HDL: High Density Lipoprotein; kg: Kilogram; L*: Lightness; MDA: Malondialdehyde; mg: Milligram; MUFA: Monounsaturated Fatty Acids; PUFA: Polyunsaturated Fatty Acids; SFA: Saturated Fatty Acids; TBA: Thiobarbituric Acid; UFA: Unsaturated Fatty Acids; $\Sigma n-9:$ Total Omega-9 Fatty Acids}

\section{Acknowledgements}

Not applicable.

\section{Funding}

This article has been prepared from the master's thesis of Hasan Huseyin IPCAK supported by TUBITAK "2210-C Domestic Graduate Scholarship Programme for Priority Areas" and EGETAV company in Izmir/Turkey. He is also thankful to TUBITAK for financial support during my thesis period. Besides, the authors gratefully acknowledge financial support from Faculty Member Training Program (ÖYP)

\section{Availability of data and materials}

Authors approved the data and materials availability.

\section{Authors' contributions}

AA supervised the research trial and also involved in data interpretation. $\mathrm{HH}$ was principal author who was responsible to manage all activities of the experiment, involved in data collection and interpretation, analyzed collected data and also wrote the manuscript. Also all authors read and approved the final manuscript.

\section{Ethics approval}

All experimental procedurs involving animals were conducted in accordance with the Animal Experimental Guidelines provided by the Ege University Ethical Committee (No: 2014-013).

\section{Consent for publication}

Not applicable.

\section{Competing interests}

The authors declare that they have no competing interests.

\section{Publisher's Note}

Springer Nature remains neutral with regard to jurisdictional claims in published maps and institutional affiliations.

Received: 19 September 2017 Accepted: 23 March 2018

Published online: 30 April 2018

\section{References}

1. Keskin B, Demirbas N. Developments arised in poultry meat sector in Turkey: problems and precautions. J Agric Faculty Uludag University. 2012; 26(1):117-30.

2. Yagmur C, Gunes E. Examination of food production and consumption in terms of a balanced diet in Turkey, VII. Ankara: Agricultural Engineering Technical Congress; 2010.

3. Gurlek S, Turan O. World food crisis: reasons and Impacts. J Agric Faculty Uludag University. 2008;22(1):63-74.

4. Yucecan S. Role and importance of chicken meat in optimal human nutrition. 2014. http://www.sagliklitavuk.org/assets/userfiles/files/ uzmanlardan/Tavuk_Etinin_Optimal_Beslenmedeki_Yeri_ve_yonemi-_ Haziran_2014.pdf. Accessed 10 Feb 2018.

5. Ipcak HH, Ozuretmen O, Ozelcam H, Unlu HB. Natural Preservatives and Mechanisms of action on animal nutrition. J Anim Prod. 2017:58(1):57-65.

6. Simsek UG, Guler T, Ciftci M, Ertas ON, Dalklic B. The effect of an essence oil mix (derived from oregano, clove and Anise) on body weight and carcass characteristic in broiler. http://vfdergi.yyu.edu.tr/archive/2005/16_2/2005_ 16 (2) 1-5.pdf. YYU Vet Fac J., 2005: 16 (2), 1-5. Accessed 22 Sept 2016.

7. Ceylan N, Ciftci I, Ilhan Z. The effects of some alternative feed additives for antibiotic growth promoters on the performance and gut microflora of broiler chicks. Turk J Vet Anim Sci. 2003;27:727-33.

8. Oskay D, Oskay M. Biotechnological importance of plant secondary metabolites. e-J New World Sci Acad. 2009;4(2):5A0006.

9. Shah J. Plants under attack: systemic signals in defence. Curr Opin Plant Biol. 2009;12:459-64

10. Kumar A, Irchhaiya R, Yadav A, Gupta N, Kumar S, Gupta N, Kumar S, Yadav V, Prakash A, Gurjar H. Metabolites in plants and its classification. World J Pharm Pharm Sci. 2015;4(1):287-305.

11. Kahraman Z. Herbal extracts and their usage in laying hen diets. J Poultry Res. 2009:8(1):34-41. ISSN:1302-3209

12. Saad NY, Mullerb CD, Lobstein A. Major bioactivities and mechanism of action of essential oils and their components. Flavour Fragr J. 2013;28:269-79.

13. Jamroz D, Wiliczkiewicz A, Wertelecki T, Orda J, Skorupinska J. Use of active substances of plant origin in chicken diets based on maize and locally grown cereals. Br Poult Sci. 2005;46:485-49.

14. Catala Gregori P, Mallet S, Travel A, Orengo J, Lessire M. Efficiency of a prebiotic and a plant extract alone or in combination on broiler performance and intestinal physiology. Can J Anim Sci. 2008:88(4):623-9.

15. Viktorija M, Liljana KG, Tatjana R, Ana C, Rubin G. Antioxidative effect of capsicum oleoresins compared with pure capsaicin. IOSR J Pharm. 2014; 4(11):44-8.

16. Newcomb MD. Herbs as a source of nutrition versus herbs as a source of drugs: A matter of claims, biology and regulations. Proc. of Alltech's 15th Annu. Symp., Biotehn. in the Feed Industry. Alltech Technical Publications, Nottingham University Press. Nicholasville, KY. 1999. p. 295-300.

17. SMA ET. Effect of using cinnamon powder as natural feed additive on performance and carcass quality of broiler chicks. Int J Innov Agric Biol Res. 2014;2(3):1-8

18. Ciftci M, Simsek UG, Yuce A, Yilmaz O, Dalkilic B. Effects of dietary antibiotic and cinnamon oil supplementation on antioxidant enzyme activities, cholesterol levels and fatty acid compositions of serum and meat in broiler chickens. Acta Vet Brno. 2010;79:33-40.

19. NRC. Nutrient requirements of poultry: Ninth revised edition. 1994. National Academy Press. Washing, D.C.

20. Naumann C, Bassler R. Chemical analyses of feedstuff, method book III. 3rd ed. Darmstad: VDLUFA Press; 1993.

21. Bulgurlu S, Ergul M, 1978. Physical, chemical and biological analysis methods of feeds. E.U. Printing House No: 127. Izmir. 1978: 176.

22. TSI. Turkish Standardization Institute. Determination of metabolic (convertible) energy in animal feed. TSE No: 9610, Ankara. 1994.

23. ISO. International Organization of Standardization. Sensory analysis General guideline for the selection, training and monitoring of assessors. Part 1: Selected assessors. ISO 8586-1 Standard. 1st ed. Geneva: ISO; 1993. 
24. ISO. International Organization of Standardization. Sensory analysis methodology - flavour profile methods ISO 1985. Geneva: ISO; 1985.

25. Kim ES, Liang YR, Jin J, Sun QF, Lu JL, Du YY LC. Impact of heating on chemical compositions of green tea liquor. Food Chem. 2007;103:1263-7.

26. Mortensen M, Andersen HJ, Engelsen SB, Bertram HC. Effect of freezing temperature, thawing and cooking rate on water distribution in two pork qualities. Meat Sci. 2006;72:34-42.

27. Honikel KO. Reference methods for the assessment of physical characteristics of meat. Meat Sci. 1998;49:447-57.

28. Grau R, Hamm R. A simple method for the determination of water binding in muscles. Naturwissenschaften. 1953;40:29-30.

29. Malovrh S, Hriberšek K, Terčič D, Volk M, Žlender B, Polak T, Holcman A. Sensory traits of capon meat in three chicken genotypes. Acta Argic Slovenica. 2009;94:17-26.

30. Witte VC, Krause GF, Bailey ME. A new extraction method for determining 2thiobarbituric acid values of pork and beef during storage. J Food Sci. 1970; 35:582-5.

31. Tarladgis BG, Watts BM, Younathan MT, Dugan L. A distillation method for the quantitative determination of malonaldehyde in rancid foods. J Am Oil Chem Soc. 1960;37:44-8

32. Anonymous. German standard methods for the investigation of fats, fat products and related substances (1959-1981), method C-VI 11a (81) Stuttgart: Scientific Publisher; 1987.

33. Folch J, Lees M, Stanley GHS. A simple method for the isolation and purification of total lipids from animal tissues. J Biol Chem. 1957:226:497-509.

34. AOAC. Official Methods of Analysis. 13th edition. Washington, DC, Association of Official Analytical Chemist. 1980.

35. SPSS. PASW Statistics for Windows, Version 18.0. Chicago: SPSS Inc.; 2012.

36. Alfaig $\mathrm{E}$, Angelovičova M, Kral M, Bučko O, Walczycka M. Influence of probiotics and thyme essential oil on the sensory properties and cooking loss of broiler chicken meat. Anim Sci Biotechnol. 2014;47(1):425-32.

37. Kirkpinar F, Unlu HB, Serdaroglu M, Turp GY. Effects of dietary oregano and garlic essential oils on carcass characteristics, meat composition, color, $\mathrm{pH}$ and sensory quality of broiler meat. Br Poult Sci. 2014;55(2):157-66.

38. Alfaig $E$, Angelovicova $M$, Kral M, Vietoris $V$, Zidek R. Effect of probiotics and thyme essential oil on the texture of cooked chicken breast meat. Acta Sci. Pol., Technol. Aliment. 2013;12(4):379-84.

39. Shirzadegan K, Falahpour P. The physicochemical properties and antioxidative potential of raw thigh meat from broilers fed a dietary medicinal herb extract mixture. Open Vet J. 2014;4(2):69-77.

40. Symeon GK, Athanasiou A, Lykos N, Charismiadou MA, Goliomytis M, Demiris N, Ayoutanti A, Simitzis PE, Deligeorgis SG. The effects of dietary cinnamon (Cinnamomum zeylanicum) oil supplementation on broiler feeding behaviour, growth performance, carcass traits and meat quality characteristics. Ann Anim Sci. 2014;14(4):883-95.

41. Elmali DA, Yakan A, Kaya O, Elmali M, Onk K, Sahin T, Durna O. Effects of plant extracts and (essential) oil mixture on breast meat quality of Japanese quails (Coturnix coturnix japonica). Revue Méd Vét. 2014;165(3-4):104-10.

42. Yetisir R, Karakaya M, Ilhan F, Yilmaz MT, Ozalp B. Effects of different lighting programs and sex on some broiler meat quality properties affecting consumer preference. Anim Prod. 2008;49(1):20-8.

43. Zhuang H, Savage EM. Comparisons of sensory descriptive flavor and texture profiles of cooked broiler breast fillets categorized by raw meat color lightness values. Poult Sci. 2010;89:1049-55.

44. Cavitt LC, Youm GW, Meullenet JF, Owens CM, Xiong R. Prediction of poultry meat tenderness using razor blade shear, Allo-Kramer shear, and sarcomere length. J Food Sci. 2004;69:11-5.

45. Chumngoen W, Tan FJ. Relationships between descriptive sensory attributes and physicochemical analysis of broiler and Taiwan native chicken breast meat. Asian Australas J Anim Sci. 2015;28(7):1028-37.

46. Kavouridou K, Barroeta AC, Villaverde C, Manzanilla EG, Baucells MD. Fatty acid, protein and energy gain of broilers fed different dietary vegetable oils. Span J Agric Res. 2008;6(2):210-8.

47. Fotea L, Costăchescu E, Hoha G, Leonte D. The effect of oregano essential oil (Origanum vulgare I) on broiler performance. Lucrări Ştiințifice Seria Zootehnie. 2010;53:253-6.

48. Duarte KF, Junqueira OM, Borges LL, Rodrigues E, Filardi RS, Praes MF, Laurentiz AC, Domingues CF. Performance, carcass traits, and body composition of broilers fed different linseed oil levels between 21 and 56 days of age. Braz J Poultry Sci. 2013;15(4):55-60.
49. Luna A, Lábaque MC, Zygadlo JA, Marin RH. Effects of thymol and carvacrol feed supplementation on lipid oxidation in broiler meat. Poult Sci. 2010;89: 366-70.

50. Faix S, Faixova Z, Placha I, Koppel J. Effect of Cinnamomum zeylanicum essential oil on antioxidative status in broiler chickens. Acta Vet Brno. 2009; 78:411-7.

51. Kim DK, Lillehoj HS, Lee SH, Jang SI, Bravo D. High-throughput gene expression analysis of intestinal intraepithelial lymphocytes after oral feeding of carvacrol, cinnamaldehyde, or Capsicum oleoresin. Poult Sci. 2010;89:68-81.

52. Lillehoj HS, Kim DK, Bravo DM, Lee SH. Effects of dietary plant-derived phytonutrients on the genome-wide profiles and coccidiosis resistance in the broiler chickens, from international symposium on animal genomics for animal health (AGAH 2010). BMC Proc. 2011:5(Suppl 4):3.

53. Bolukbasi SC, Erhan MK, Ozkan A. Effect of dietary thyme oil and vitamin E on growth, lipid oxidation, meat fatty acid composition and serum lipoproteins of broilers. South Afr J Anim Sci. 2006;36(3):189-96.

54. Shin D, Kakani G, Karimi A, Cho YM, Kim SW, Ko YG, Shim KS, Park JH. Influence of dietary conjugated linoleic acid and its combination with flaxseed oil or fish oil on saturated fatty acid and n-3 to n-6 fatty acid ratio in broiler chicken meat. Asian-Aust J Anim Sci. 2011;24(9):1249-55.

55. Sadeghi AA, Iravani $H$, KarimiTorshizi MD, Chamani M. Fatty acids profiles in meat of broiler chicks fed diet containing corn oil switched to fish oil at different weeks of age. World Applied Sciences Journal. 2012;18(2):159-65.

56. Bayizit AA. The importance of polyunsaturated fatty acids in diet and health. Food Feed Sci Technol. 2003:3:28-31.

57. Eseceli $H$, Degirmencioglu A, Kahraman R. Omega fatty acids are important for human health. Turkey 9th Food Congress. 24-26 2006.

\section{Submit your next manuscript to BioMed Central and we will help you at every step:}

- We accept pre-submission inquiries

- Our selector tool helps you to find the most relevant journal

- We provide round the clock customer support

- Convenient online submission

- Thorough peer review

- Inclusion in PubMed and all major indexing services

- Maximum visibility for your research

Submit your manuscript at www.biomedcentral.com/submit
) Biomed Central 